УДК 398

ББК 82.3
СИСИНИЕВА ЛЕГЕНДА В ФОЛЬКЛОРНЫХ И РУКОПИСНЫХ ТРАДИЦИЯХ ЕВРАЗИИ И АФРИКИ (ИТОГИ И ПЕРСПЕКТИВЫ ИССЛЕДОВАНИЯ)

\author{
(C) 2019 г. А.Л. Топорков \\ Институт мировой литературы \\ им. А.М. Горького Российской академии наук, \\ Москва, Россия \\ Дата поступления статьи: І5 июля 2018 г. \\ Дата публикации: 25 июня 2019 г.
}

DOI: I0.22455/2500-4247-20I9-4-2-3I2-34I

Аннотация: В статье излагаются основные результаты коллективного труда «Сисиниева легенда в фольклорных и рукописных традициях Ближнего Востока, Балкан и Восточной Европы» (20I7). Исследование позволило вывить и проанализировать различные версии и редакции мифологических текстов о святом Сисинии, противостоящем женскому демону, известные в арабской, арамейской, армянской, болгарской, греко-византийской, еврейской, коптской, новогреческой, румынской, русской, сербской, сирийской, украинской, эфиопской и некоторых других культурах. Два основных сюжетных типа Сисиниевой легенды фиксировались на протяжении примерно полутора тысяч лет: с середины I тысячелетия нашей эры до XX в. Тексты Сисиниевой легенды разнообразны в видовом и жанровом отношениях: мифологические нарративы, религиозные легенды, агиографические повествования, заговоры, заклинания, молитвы. Установлены особенности сюжета Сисиниевой легенды у разных народов, состав персонажей и их имен, взаимодействие текстов в рукописных и устных традициях. В научный оборот введены тексты, представленные на арамейских магических чашах, эфиопских и еврейских амулетах, а также включенные в греческие, армянские, румынские и другие рукописи. Доказано, что у русских и украинцев Сисиниева легенда трансформировалась в заговоры от лихорадки, которые бытовали на территории Украины и в европейской части России, а также в Сибири и на Дальнем Востоке.

ключевые слова: Сисиниева легенда, заговоры, молитвы, агиография, рукописи, магия, демоны, иконография, имена собственные.

Информация об авторе: Андрей Львович Топорков - член-корреспондент РАН, доктор филологических наук, главный научный сотрудник, Институт мировой литературы им. А.М. Горького Российской академии наук, ул. Поварская, д. 25 а, I2I069 г. Москва, Россия. ORCID ID: 000о-0002-3106-38I9

E-mail: atoporkov@mail.ru

Для цитирования: Топорков А.Л. Сисиниева легенда в фольклорных и рукописных традициях Евразии и Африки (итоги и перспективы исследования) // Studia Litterarum. 20I9. T. 4, № 2. C. 3I2-34I. DOI: IO.22455/2500-4247-2OI9-4-2-3I2-34I 


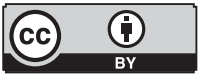

This is an open access article distributed under the Creative Commons Attribution 4.0 International (CC BY 4.0)

\section{ST SISINNIUS' LEGEND IN FOLKLORE AND HANDWRITTEN TRADITIONS OF EURASIA AND AFRICA (OUTCOMES AND PERSPECTIVES OF RESEARCH)}

(C) 20I9. A.L. Toporkov

A.M. Gorky Institute of World Literature

of the Russian Academy of Sciences,

Moscow, Russia

Received: July I5, 2018

Date of publication: June 25, 2019

Abstract: The article presents the main results of a group research entitled "St. Sisinnius' Legend in Folklore and Written Traditions of the Near East, Balkans, and Eastern Europe" (20I7). This research has allowed the discovery and analysis of different versions of mythological texts (which are known in Arabic, Aramaic, Armenian, Bulgarian, Byzantine Greek, Jewish, Coptic, Modern Greek, Romanian, Russian, Serbian, Syriac, Ukrainian, Ethiopian, and some other traditions) about St Sisinnius counteracting a female demon. Two main types of plots of St Sisinnius' Legend (SL) have been recorded since the middle of the first millennium A. C. till the $2 \mathrm{O}^{\text {th }}$ century, approximately one thousand and a half years. SL texts are quite diverse in the terms of genres and forms, including mythological narrations, religious legends, hagiographical stories, charms, incantations and prayers. This article identifies the specificity of SL's plot among different nations, the list of characters and their names, and the interrelation between texts in handwritten and oral traditions. Texts inscribed on Aramaic magical cups, Ethiopian and Jewish amulets, and also texts included in Greek, Armenian, Romanian and other manuscripts were introduced into the research data base. It was proved that among Russians and Ukrainians SL transformed into charms against fever that were spread on the territory of Ukraine and the European part of Russia, Siberia, and the Far East.

Keywords: legend about St Sisinnius, verbal charms, prayers, hagiography, manuscripts, magic, demons, iconography, proper names.

Information about the author: Andrey L. Toporkov, Corresponding Member of RAS, DSc in Philology, Director of Research, Professor, A.M. Gorky Institute of World Literature of the Russian Academy of Sciences, Povarskaya 25 a, I2Io69 Moscow, Russia. ORCID ID: 0000-0002-3106-3819

E-mail: atoporkov@mail.ru

For citation: Toporkov A.L. St Sisinnius' Legend in Folklore and Handwritten Traditions of Eurasia and Africa (Outcomes and Perspectives of Research). Studia Litterarum, 2019, vol. 4, no 2, pp. 3I2-34I. (In English) DOI: IO.22455/2500-4247-20I9-4-2-3I2-34I 
The mythological texts about St. Sisinnius counteracting a female demon are known in Arabic, Aramaic, Armenian, Bulgarian, Byzantine Greek, Georgian, Jewish, Coptic, Latvian, Lithuanian, Modern Greek, Romanian, Russian, Serbian, Syriac, Ukrainian, Ethiopian, and various other traditions. St. Sisinnius' Legend (SL) is spread on the territories of Near East, Balkans, the Caucasus, North-Eastern and Eastern Africa. Among Russians and Ukrainians SL has transformed into charms for fever, which existed on the territory of Ukraine and the European part of Russia, Siberia, and the Far East of Russia. SL has been recorded since the middle of the first millennium A.C. till the $2 \mathrm{O}^{\text {th }}$ century, approximately one thousand and a half years.

For the last 150 years folklore researchers, historians of literature and culture, linguists, and researchers of theology have paid their professional attention to SL. The legend has been investigated in countries such as Great Britain, Bulgaria, Germany, Greece, Israel, Poland, Russia, Romania, Serbia, Finland, France, the USA, and others. The general bibliography of publications devoted to SL at the present time includes many hundreds of articles and could be a subject for additional research.

Reviews of literature dedicated to the research of SL in Aramaic, Armenian, Byzantine Greek, Eastern Slavic, Modern Greek, Jewish, Coptic, Romanian, Syriac, Ethiopian, and Southern Slavic traditions are mentioned at the beginning of each corresponding chapter in the book.

The first researchers of SL mainly based their works on Byzantine Greek, Southern Slavic, and Romanian traditions, in which the coexistence of two types of plots is typical. Moses Gaster called one of them Sysoi-type, in reference to the name of the character who takes the place of St Sisinnius in a Romanian version 
of SL. Another he called Aveshtitsa-type, according to the name of the demoness [21]. Richard Greenfield, using Byzantine-Greek material later defined these types as Mikhail-type and Sisinnius/Melitene-type [23].

The Mikhail-type plot is represented in oral charms and records on amulets. "One is the most well spread texts for charms for women in labor (known in many languages of people of the Near East and Eastern Europe who used it later against the evil-eye and other diseases) tells of some saint (either Ilya, Mikhail, Sisinnius, or another) who often in texts has come down a road on a hill, meets a witch (usually near the sea coast), and asks where she is going. Having heard that she is going in the house of a women who is going into labor with the purpose to harm her, he forces her to say $9(\mathbf{I 2}, 40)$ of her names and swear that she will not harm the baby if she sees all of her names in the house. Amulets and charms for women in labor against Lilit must consist of not only three names of angels who tried to bring back Lilit, but also the names of Lilit herself” [ı].

According to Sisinnius/Melitene-type, the demoness kidnaps and kills the children of Melitene, her brother Sisinnius chases after the criminal, catches her, and forces her to bring back the children alive. At the end of the text the demoness says all of her names and promises not to touch people who pronounce all her names and/or the name of Sisinnius or keep the record of all these names.

Under the name of "St Sisinnius' Legend" at least two plots are mentioned which include common situations, episodes, and characters; however the plots may more or less significantly differ from each other.

SL is indefinite enough in character as to which genre it pertains to. For most texts the combination of narrative, religious, and incantational (magical) influences is typical. In different ethnographical and language versions and plot types these elements are represented in different proportions. For example, texts of the Mikhail-type may be close to charms, but texts of the Sisinnius/Melitene-type sometimes grow into a history of the saint's life.

Some traditions know two types of SL plots, but other traditions know only one of them. Even when two plots may be strongly different from each other they have something in common. In particular, in both plots characters meet each other and start a dialogue. Texts with this episode are known in many traditions and are marked as Encounter-charms (in German "Begegnungssegen"). Danish researcher Ferdinand Ohrt pointed out that encounter charms have three parts: a composition (including an introduction), dialogue, and then a final part. Also 
there is a description of two or several characters and their interactions which leads to the improvement of the situation. Ohrt emphasized several types of encounter charms. SL belongs to those where a sacred character meets a personified disease or an evil spirit, starts a dialogue with it, and after chases it out [24, p. I592-I593].

In the two plot types of SL known in Byzantine-Greek, Southern Slavic, and Romanian traditions we may emphasize seven common parameters. First, SL texts have magical functions and represent charms or non-canonic prayers aimed to protect pregnant women, women in labor, and babies from the evil-eye and bad luck. Second, there are at least two characters in the text (the sacred male and the demonic female), but it could be more characters as long as the division into two opposite groups is constant. Thirdly, the male character sometimes has a name of Sisinnius and/or names which are phonetically similar. If he is a member of a group of two, three, or more characters, their names then also resemble the name of Sisinnius. Fourth, there is a female demonic character who brings harm to pregnant women, women in labor, or newborn babies. Fifth, the text belongs structurally to the type of Encounter-charms, which includes a meeting between characters and their dialogue. In Mikhail-type the whole text is an Encounter-charm, but in Sisinnius/Melitene-type an Encounter-charm is only one of the episodes, which usually serves as the end of the narration. Sixth, the sacred character forces the demoness to tell her name and then she tells him her name and even her whole series of names. This list of names may include understandable words and unrecognizable words. Seventh, at the end a demoness swears not to enter the house where all her names will be pronounced or preserved in written form of a charm with her names and/or the names of Sisinnius and other saints.

While the presence of all seven parameters in any text allows for the identification of it as SL, none of these parameters are obligatory for identification. In particular, in many SL versions the name of Sisinnius is absent. It is not always that we meet the opposition of character according to their gender and the number of them can vary. The dialogue usually consists of 3 lines, but in separate cases it can be more or less.

While doing research on the genesis of SL plot types, we submit to consideration all those traditions in which different variants of SL were represented. In particular, we analyzed the episode of Obyzouth from "The Testament of Solomon," Aramaic texts of the history of Smamit, Jewish texts about Lilit and 
three angels, about Lilit and Ilijah the Prophet, Ethiopian texts about Sisinnius and Werzelya, Syriac texts about Avdisho and Teb'ah or Simon Keefa and Teb'ah, Greek texts about St Sisinnius and Melitene or Archangel Michael and Gylou, Armenian texts about Sisinnius, Al, and Tpcha, Southern Slavic texts about Sisinnius and Melitene or Archangel Michael and a veshtitsa, Romanian texts about Sysoi and Avestitsa, and Russian and Ukrainian charms against seven or twelve tryasavitsy ${ }^{\mathrm{I}}$ (fever).

\section{The History and Geography of Sisinnius/Melitene-type}

In Byzantine-Greek, Southern Slavic, and Romanian traditions, from which the investigation of SL started in the $19^{\text {th }}$ century, the two types of plots are known and they are conditionally named as Mikhail-type and Sisinnius/Melitene-type, by R. Greenfield. Moreover, texts with these plots may be included in the same manuscripts, placed one under another, and even be contaminated. Our research has shown that these types of plots are not connected by origin. Their convergence apparently was a secondary phenomenon and took place through the Byzantine-Greek connection. The earliest texts of Sisinnius/Meletene-type were documented in Aramaic records on clay cups from Babylon (from the $4^{\text {th }}-8^{\text {th }}$ century) and on metal amulets from the Syria-Palestine area. In the version A of "The Story of Smamit," the main events of this plot type have already been presented. First, Siderous kills the children of Smamit and then Smamit builds a house for herself and hides inside. Soon, three angles come to her and ask to be allowed to come in, but Siderous sneaks inside the house with the angels and kills one more child of Smamit. The angels follow Siderous and catch him in the middle of the sea. There Siderous asks for mercy and promises not to kill children in the place where the names of the three angels would be pronounced [5].

Despite of the similarity with the classical plot of Sisinnius/Melitene-type in Byzantine-Greek tradition, this text significantly differs from it. Demon Siderous is male, not female. After the angles catch up to Siderous he swears not to kill children, but there is no motif of returning earlier killed or kidnapped children in the text and neither is there a motif of interrogating the demon to tell his names. In the demon's oath only names of angels are mentioned, but not of the demon

I A female personification of fever. The name came from the Slavic root "tryasti," which means to shake. 
himself and the means of protection from him is the pronunciation of names, not the record of them on an amulet.

This Aramaic version seems to be the original for all the following versions of Sisinnius/Melitene-type, which can be united in several cultural cycles: I) Byzantine-Greek, Southern Slavic, Romanian, and Greek, 2) Jewish, 3) Coptic, and Ethiopian, 4) Syriac.

I) For Byzantine-Greek, Southern Slavic, and Romanian traditions within the Sisinnius/Melitene-type, it is typical for the appearance of new characters and additional episodes. The place of three angels is taken by Sisinnius and his three brothers. The place of Smamit is taken by Melitene and instead of Siderous in the Byzantine-Greek tradition, there is Gylou and the devil. In Southern Slavic tradition, there are veshtitsa and the Devil. In Romanian tradition, there are Avestitsa and the devil. A demoness and the devil bring back children that were earlier killed or kidnapped, but in Aramaic records on cups and amulets there is no such an episode.

In the story about following Gylou or the devil a series of episodes is additionally included. Sisinnius meets trees on the road and asks them if they have seen the demoness and depending on their answer, he either curses or blesses them. The demoness turns into a fish, a bird, or a hair and accordingly, the saints turn into fishermen or birds of prey or they ask the tsar for permission to tear a hair from his beard. Gylou or the devil gives his followers a complicated task. For example, he asks them to regurgitate their mother's milk and they successfully resolve the task [i7]. All these changes and additions to the plot Sisinnius/ Melitene-type appear most likely in Byzantine-Greek and later are preserved in Southern Slavic, Romanian, and Modern Greek traditions. But the earliest records of Slavic texts of Sisinnius/Melitene-type we have access to chronologically precede Byzantine-Greek texts [I; 9; Io].

2) The Jewish legend about three angels and Lilit in their final part have several common features with the Aramaic "Story of Smamit." In both traditions there are 3 angels and a demon who puts harm on little children. In Jewish texts Lilit runs away to the sea where angels catch up to her and she swears not to put harm in the place where the names of angels will be pronounced or kept in written form. The most reliable point which confirms the closeness of Aramaic and Jewish texts is the similarity of the names of the three angels, which also include the consonants "s" and " $n$ ".

The rest the Jewish legend differs from the Aramaic one, as Lilit takes the place of Siderous and the beginning in Jewish texts is absolutely different. 
Instead of the story telling about Siderous' murder of Smamit's children, there is a story about the creation of the first people, a quarrel between Adam and Lilith, and her escape from paradise. We cannot exclude that during the compilation of the Aramaic legend about Siderous and the Jewish legend about the three angels and Lilit, there were common mythological motifs used which were known a long time before in traditions from Syria-Palestine and nearby territories.

The three angels (Sinui, Sinuni, and Samanglaph) were first mentioned during the $8^{\text {th }}-9^{\text {th }}$ centuries A.D. The first such story about Lilit, three angels, protectors, and an amulet for newborn babies was recorded in "Alphabet of Ben Sirach" (end of the $\mathrm{IO}^{\text {th }}$ century A.D.) [4].

3) The origins of the Coptic and Ethiopian versions of Sisinnius/Melitene-type can be connected with the Byzantine-Greek version and with the edited version B of the Aramaic "Story of Smamit." Scenes of killing a child or several children exist in the introduction to the Ethiopian version and also in the Aramaic and Byzantine-Greek, however, in some details they are all different. While in all three versions there is a chase after a demon and his punishment, in the Ethiopian texts, in place of the three angels in the Aramaic legends, St Sisinnius appears in the image of an armed rider. The same is in Byzantine-Greek texts, but in the last ones St Sisinnius usually acts not alone, but accompanied by two other riders.

The Coptic and Ethiopian texts were documented relatively late, but on the base of iconographic materials (the fresco from Bawit and Coptic textiles) it is possible to state that the legend about Sisinnius the rider killing the demoness was already known in Egypt in the $6^{\text {th }}-7^{\text {th }}$ centuries A.D. [3]. W. Worrell pointed out the connection between the Ethiopian version of the legend with the Coptic and Greek versions. He guessed that it came to Ethiopia from Egypt in the $\mathrm{I} 4^{\text {th }}-\mathrm{I} 5^{\text {th }}$ centuries $[27$, p. 400]. In "The Chronicles of Tsar Sisinnius," at the beginning of the $\mathrm{I}^{\text {th }}$ century it was mentioned that Sisinnius (ruled from I607I632) was named in the honor of Martyr Sisinnius, who took a victory over the witch Werzelya. At the end of the $16^{\text {th }}$ century the legend was well known in Ethiopia [18, p. 203].

The Ethiopian version of SL is known in two editions, which are significantly different from each other. One is spread in magic manuscripts and the other in hagiographic works about St Sisinnius. The hagiographic edition is known in 
a short (synaxarion) sub-edition and in the long sub-edition included in "Gadla Sama'etat." Texts of the short sub-edition are also included in magic manuscripts.

The hagiographic version differs from the "magic" one, first of all because in the first one a witch is the sister of St Sisinnius. First, she kills her daughter and drinks her blood and then she gives birth to a strange child from Satan. St Sisinnius stabs his sister and her son with a spear. In the synaxarion hagiography sub-edition this episode is shorter than in the long sub-edition. Some details are absent, but in general the plot of the legend in both sub-editions coincide. The source of family conflict we may see in edition B of the Aramaic "Story of Smamit" where Smamit plays not the role of victim, but strangler and the angels (Sini, Sasini, Snigri, and Artiki) try to strangle her and kill her son [5, p. 58].

The 'magical' edition of the legend of St Sisinnius has more spread and detailed character in comparison with a hagiographic text. The man named Sisinnius is married and has children who are kidnapped by the witch Werzelya. This man or his patron saint chases Werzelya and meets an old woman, whom he asks where the witch has gone. She directs him to the garden and there Sisinnius finds Werzelya under a tree. He addresses his prayer to Jesus Christ and then stabs her side with a spear. In the end, Werzelya swears not to visit the place where people read the hagiography of St Sisinnius. Such episodes as the chase, Sisinnius' prayer addressed to the Lord, and the demoness swearing have parallels in ByzantineGreek texts. Such episodes as meeting an old woman and then Werzelya in the garden can be found only in Ethiopian variants of SL and it is possible they were formed locally [2].

4) In the Syrian texts "The Incantation of Simon Keefa against Teb'a" the main hero is the apostle Peter. The first part of the texts resemble the Acts of the Apostles and biblical stories about Ilijah the Prophet. At the same time, some episodes are close to the plot of Sisinnius/Melitene-type. The wife of the tsar had seven sons, but not even the last newborn could survive. Simon Keefa ties the demon and it tells him that he is killing babies inside the bellies of their mothers. Simon Keefa then puts an incantation on the demon so that it will have no power where people remember the holy names of Jesus Christ and Simon Keefa. The list of the demon's names is absent and protection is guaranteed only by the names of saints [8]. 
Stemma I. Relationships Between Versions of the Sisinnius/Melitene-type

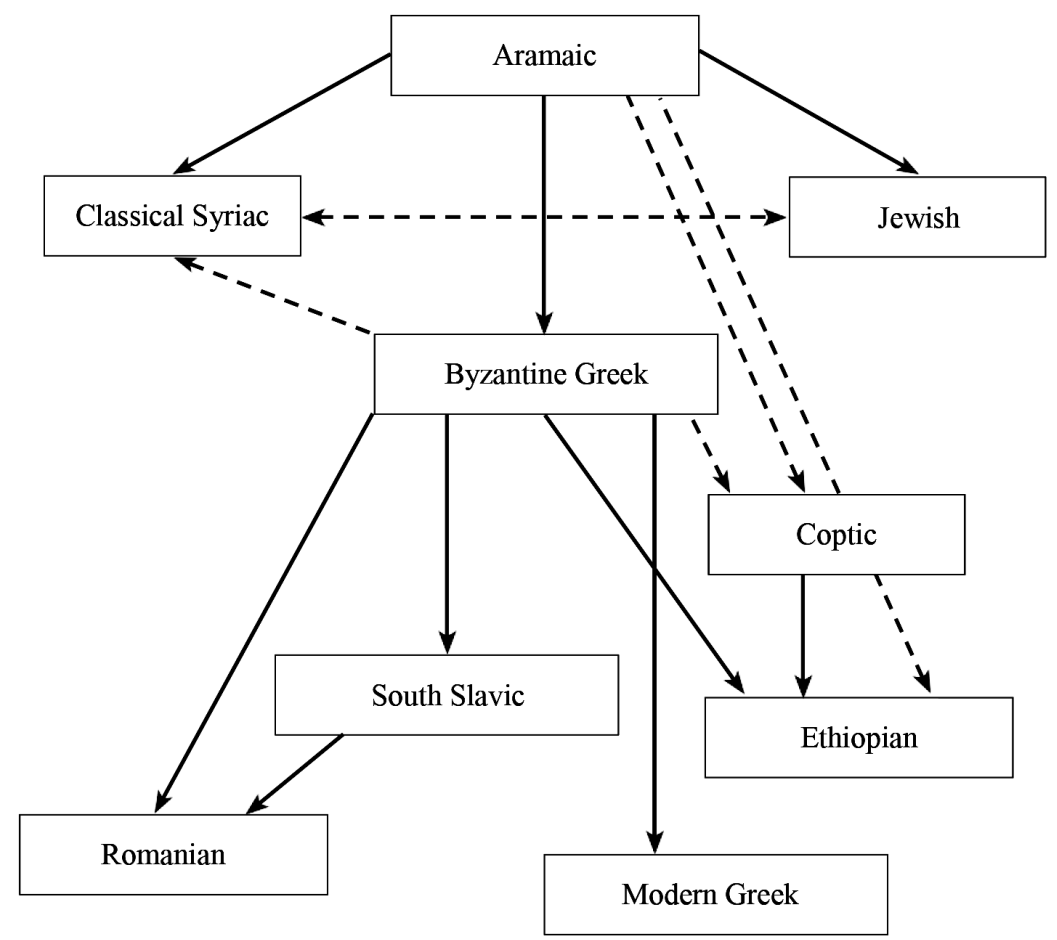

\section{The spread of the Mikhail-type}

The prehistory of this type of plot is connected with the episode of meeting Solomon and the female demon, Obyzouth. This episode is known in "The Testament of Solomon" (TS), but it is not excluded that it also existed in oral tradition as an independent text in Jewish and/or Greek languages or was used as an apotrope, like a shorter version of the $18^{\text {th }}$ chapter from TS about zodiac spirits and defense against them that has been preserved as an amulet written on papyrus in the $6^{\text {th }}$ century A.C. [26, pp. I62-I64]. In TS, this episode stands in one line with many others having the same structure and were used against demons. It can be considered as a structure based on Mikhail-type texts in the following traditions and the influence of TS on Mikhail-type could be either direct or indirect. However, the Mikhail-type structure has a sort of universal 
character, so it could be transferred or reconstructed in new forms independently from TS.

TS appeared possibly near the $4^{\text {th }}$ century A.C., but some original edition could have already existed in the $\mathrm{I}^{\text {st }}$ century A.C. TS manuscripts were basically known no earlier than the $15^{\text {th }}-16^{\text {th }}$ century. TS has been preserved in the Greek language, but it could have been formed in the Jewish environment, for example in Jerusalem. So we may assume that the basis of the Mikhail-type plot had already been constructed by the $4^{\text {th }}$ century A.C. and existed in the Hellenistic bilingual Jewish environment of Jerusalem or neighboring territories. Later, Mikhail-type charms could have been spread among the population of the Byzantine Empire, which spoke Greek, Aramaic, Old Jewish, and other languages [6].

According to the witness of Flavius Josephus (The Antiquities of the Jews, 8.2.5), Solomon was believed to control demons and compose incantations. On engraved gems of late antiquity Solomon was depicted as a rider with a spear, stabbing a female demon. In the following traditions, the place of a rider was taken by St Sisinnius [I3, p. 758-770]. Different Mikhail-type versions could possibly be united in several cultural circles: I) Byzantine-Greek, Southern Slavic, Romanian, and Modern Greek, 2) Jewish, 3) Arabic, 4) Classical Syriac, 5) Armenian, and 6) Eastern Slavic.

I) In Byzantine-Greek tradition, a special version of Mikhail-type had already been formed by the $8^{\text {th }}$ century A.C. It preserved some ties with the episode from TS, but has all the basic features of the Balkan versions of SL. The earliest record of the Byzantine-Greek Mikhail-type version in Greek was discovered on a lead tablet from Cyprus ( $8^{\text {th }}$ century) published in 2004 [22]. The direct connection with TS is proven by the common general structure, the name of a female demon Avizu, and the description of her appearance. In comparison with TS, there are a set of new details and episodes in the text. In particular, the place of Solomon in the charm is taken by Archangel Michael, who was coming down from Mount Sinai and a female demon calls all her names [I7, pp. 246, 27I-273). We will meet all of these elements later in Mikhail-type charms recorded from the Greeks, Southern Slavs, and Romanians and in the transformed version in the charms against fever known among Russians and Ukrainians.

2) In Jewish Mikhail-type texts, either the Prophet Ilijah or Angel Michael meets Lilit, the Star Margalit, Angel Ashtribo, or others. The earliest Mikhailtype texts in Hebrew from Crete manuscripts of the $14^{\text {th }}$ and $15^{\text {th }}$ centuries have 
a lot in common with Greek ones and are conceded as transitional forms from Byzantine-Greek to Jewish tradition [I9; 4].

3) In the Arabic text of Solomon and Umm As-Sibyan (from the amulet of "Solomon's Seven Agreements") the situation slightly resembles the episode from TS, however, it includes a common list of names for Mikhail-type texts, which doesn't exist in TS. Another Arabic text (from “The Book of Mercy”) is closer to the Byzantine-Greek, Jewish, or Syriac Mikhail-type texts [7].

4) The Classical Syriac "The Incantation of Avdisho Against the Demon Teb'a” resembles an episode from a hagiography of the Holy Anchorite. Avdisho has been living for 40 years in solitude on a mountain among animals when an evil spirit appears in the image of a disgusting woman who desires to be his wife. Avdisho asks for her name and she tells him first four of her names and then twelve more. Avdisho ties the woman and pronounces the incantation with angels' names. The structure of the text and the episode of pronouncing the names are close to the Byzantine-Greek Mikhail-type version. However, the style of the Syriac charm is different. The story about the life of anchorite Avdisho and the appearance of a woman trying to seduce him are typical for the stories about saints. It is quite possible that the Syriac "The Incantation of Avdisho Against the Demon Teb'a," did not come directly from Greek texts of the Mikhail-type, and included not only Greek titles, but titles from other traditions such as, Aramaic, Arabic, and Persian [8].

5) Armenian versions in general reproduce the Byzantine Greek plot of the Mikhail-type version. St Peter, St Paul, St Sila, and others act in the majority of Armenian texts, but such names as Sisinnius, Sisiannius, Sisiatnius, Sisiannae, Sissoi, Sissii, Siannii, and Sanos. In these texts there are colorful descriptions of the demons $\mathrm{Al}$ and Tpcha who invade a woman's belly and eat the liver of women who are in labor and the meat of their unborn children. $\mathrm{Al}$ is sometimes protected by his mother. The demons pronounce their twelve names and swear not to visit the place where all their names and the names of saints are known [I5].

6) The specific type of SL (charm or non-canonic prayer against fever) was spread among Eastern Slavs. In these texts, fever is personified as the images of 7 or 12 tryasavitsy who in their turn are identified as the daughters of Tsar Herod. Usually, a text starts with an episode when St Sisinnius is sitting on Mount Sinai and sees how I2 women with uncovered hair are coming out from the Red Sea. St Sisinnius addresses his prayer to the Lord and he responds by sending to earth 
the Angel Sikhaiel in a column of fire. St Sisinnius and Angel Sikhaiel beat the tryasavitsy, each of whom, in their turn calls their own name and explains which diseases she brings to people. In conclusion, they promise not to come close to the place where they hear the names of St Sisinnius and Angel Sikhaiel.

Eastern Slavic non-canonic prayers against tryasavitsy were formed no later than the $14^{\text {th }}$ century. It was documented in fragments on a piece of birch bark in Novgorod and in the list of non-canonic books from "The Pogodin's Nomocanon" during the border between the $14^{\text {th }}$ and $I 5^{\text {th }}$ century. This version of SL matches the iconographic plot of "The Appearance of Angel Sikhaiel to Saint Sisinnius" painted on the icon by master Lucian in I3I2 and on other samples of old Russian painted art [16].

Stemma 2: Relationships Between Mikhail-type Versions

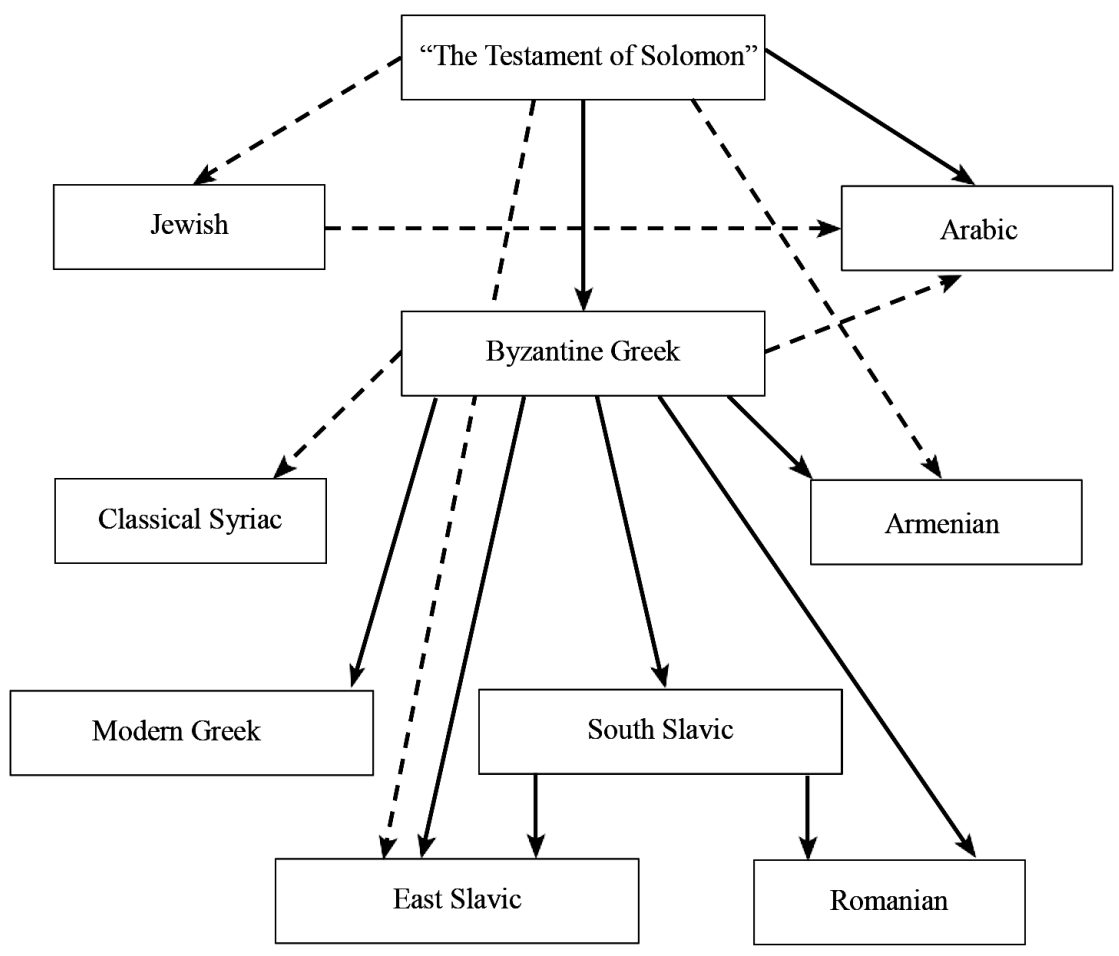


Generally, the analyzed traditions could be divided into two groups: those where there was only one type of SL and those where there were both types. Both types, Sisinnius/Melitene-type and Mikhail-type are represented in ByzantineGreek, Southern Slavic, Romanian, Modern Greek, and Jewish traditions. Texts of Sisinnius/Melitene-type are known in Coptic, Aramaic, and Ethiopian traditions, but at the same time, Mikhail-type has not been recorded there. Texts of Mikhailtype are known in Aramaic and Arabic traditions, but there the "Sisinnius/Melitina-type" has not been recorded. Syrian people knew Mikhail-type texts, but if they were familiar with Sisinnius/Melitene-type is the question under discussion. A special version of SL (which is close to Mikhail-type) is spread among Eastern Slavs, but Sisinnius/Melitene-type is unknown.

\section{Table I - Plot Types of St Sisinnius' Legend (SL) in different traditions}

\begin{tabular}{|c|c|c|c|}
\hline № & $\begin{array}{l}\text { Ethnolinguistic versions } \\
\text { of types of plots }\end{array}$ & Mikhail-type & $\begin{array}{l}\text { Sisinnius/Melitene- } \\
\text { type }\end{array}$ \\
\hline I & $\begin{array}{l}\text { "The Testament of } \\
\text { Solomon" }\end{array}$ & $\begin{array}{l}\text { The Episode with Solomon and } \\
\text { Obyzouth }\end{array}$ & - \\
\hline 2 & Aramaic & - & $\begin{array}{l}\text { "The History of } \\
\text { Smamit" }\end{array}$ \\
\hline 3 & Jewish & "Ilya the Prophet and Lilit" & $\begin{array}{l}\text { "Three Angels and } \\
\text { Lilit" }\end{array}$ \\
\hline 4 & Coptic & - & $\begin{array}{l}\text { "The Life of St. } \\
\text { Sisinnius" }\end{array}$ \\
\hline 5 & Arabic & "Solomon and Karina" & - \\
\hline 6 & $\begin{array}{l}\text { Ethiopian (magic } \\
\text { manuscripts) }\end{array}$ & - & $\begin{array}{l}\text { The legend about St } \\
\text { Sisinnius and Werzelya }\end{array}$ \\
\hline 7 & $\begin{array}{l}\text { Ethiopian } \\
\text { (hagiographic works) }\end{array}$ & - & $\begin{array}{l}\text { The Life of St. } \\
\text { Sisinnius }\end{array}$ \\
\hline 8 & Classical Syriac & $\begin{array}{l}\text { The Incantation of Avdisho Against } \\
\text { the Demon Teb'a }\end{array}$ & $\begin{array}{l}\text { The incantation of } \\
\text { Simon Keefa Against } \\
\text { the Demon Teb'a (?) }\end{array}$ \\
\hline 9 & Armenian & Charms against $\mathrm{Al}$ and Tpcha & - \\
\hline IO & Byzantine Greek & The prayer against Gylou & $\begin{array}{l}\text { The legend telling how } \\
\text { Sisinnius, Siny, and } \\
\text { Sinodore save children } \\
\text { from Melitene and } \\
\text { Gylou }\end{array}$ \\
\hline II & Modern Greek & A charm against the evil eye & $\begin{array}{l}\text { A charm against a } \\
\text { female demon }\end{array}$ \\
\hline $\mathrm{I} 2$ & South Slavic & A prayer to Archangel Michael & $\begin{array}{l}\text { A prayer to } \\
\text { St Sisinnius }\end{array}$ \\
\hline
\end{tabular}




\begin{tabular}{|l|l|l|l|}
\hline I3 & Romanian & "Avestitsa, a wing of Satan” & $\begin{array}{l}\text { The Legend about } \\
\text { St Sisinnius }\end{array}$ \\
\hline I4 & Eastern Slavic & The charms against tryasavitsy & - \\
\hline
\end{tabular}

\section{The Historical Dynamics of SL}

The analyzed material doesn't allow us to define exactly where and when these plots of SL types first appeared, but we may state that both plots had been formed by the $6^{\text {th }}$ or $7^{\text {th }}$ century A.C. and were known within the territory of the Byzantine Empire (i.e. in the provinces of the Near East and North Eastern Africa). In general, we share the idea of W. Fauth, that the territory where the basic model of the legend had first appeared should be investigated in the South Eastern periphery of the Mediterranean Sea (in Palestine, Syria, and Egypt) [20]. The problem is what should be considered as the basic model, because the term SL covers at least 2 different plots.

So both plots of SL types most likely were formed in the pre-Christian or early Christian period. The episode with Obyzouth from "The Testament of Solomon" may be considered as a proto-fable of Mikhail-type, but it has no signs of Christian influence. The same we could say about the history of Smamit, from which the documented history of Sisinnius/Melitene-type begins. Versions of SL are known in Arabic (Islam) and Jewish (Judaism) traditions. The Christianization of Mikhail-type can be followed in a Greek text of the $8^{\text {th }}$ century written on a lead tablet from Cyprus. The role of the sacred hero is taken by Michael the Archangel, who is descending from Mount Sinai and meets Avizu. The demoness tells him that she has tried to put harm on the Virgin Mary when she gave birth to the Word of Truth [I7, p. 272). Despite the fact that the text has not been fully preserved, Christian motifs can be clearly recognized in it.

Relatively, during one thousand and a half years, SL has experienced a set of natural transformations and (more or less) spontaneous ones. At the same time, the texts' dynamics cannot be understood as a primitively defined evolution. Even in the frame of one ethnic and language tradition, dynamics can have irregular character. Generally, oral texts changed faster and more dramatically than texts written in manuscripts, particularly those in published books. In the last level these processes touched Jewish tradition, which generally existed quite autonomously. 
According to SL's status (which is between folklore narration, drama scene, charm, and a magical act), the texts developed in the direction of either charms or narrations with plots. In the first case, texts as a rule became shorter, with some separate episodes, details, characters, and personal names omitted. These tendencies are mostly noticeable in places where SL had been preserved in oral forms till the $19^{\text {th }}-20^{\text {th }}$ century. For example, in Modern Greek tradition the charms against Gylou have transformed into charms against the evil eye and any misfortune. Russian magic spells against fever in their short edition lost the basic list of tryasavitsy names, the name of Sisinnius, etc. The shortage of the texts by itself did not lead to the appearance of new types, but in the cases when a text lost its significant features of SL, it could be identical to other magic spells with the structure of encounter-charms.

In the second case, just the opposite, as the texts increased in size, the plot became more complicated, included new episodes, dialogue, and the scene where the demoness is beaten was moved from the center to the periphery of the plot composition and was built in to one line with other episodes (Sisinnius/Melitenetype in the Byzantine-Greek, Southern Slavic, and Romanian traditions).

As a result of cardinal editing of the text, the encompassment of new episodes, Christianization, and genre transformation, the hagiographic versions of SL appeared in Greek, Coptic, and Ethiopian traditions, including the Syriac, "The Incantation of Avdisho Against the Demon Teb'a" and "The Incantation of Simon Keefa." In the Byzantine-Greek hagiographic composition of the $15^{\text {th }}$ century, "The Life and Acts of Christ's Saints Sisinnius and Sisinodore, Brothers of St Melitene," Sisinnius and Sisinodore are called saints and God's angels and they ask the Lord for help, but these included Christian elements do not change anything significantly within the plot. The Coptic variant of the life of St Sisinnius has been preserved in Egyptian-Arabic synaxaria. In Ethiopian written texts, two versions of St Sisinnius' hagiography are presented, the short one and the long one. The Syriac, "The Incantation of Avdisho Against the Demon Teb'a” resembles the episode from the Life of the Holy Anchorite.

In the cases of parallel SL existence in both written and oral traditions, scribes had a chance to edit the texts according to their own knowledge of local folklore as they were copying them. As a result, in some cultures we may notice a broad diversity of handwritten texts (for example, among Armenians, Russians, and Ukrainians). 


\section{The Personal Names in SL}

It is interesting to notice that the name of Sisinnius is absent in the texts which serve as originals for the whole following tradition of SL. There is no name in "The Testament of Solomon," the Aramaic "History of Smamit," in Jewish legendary texts about Lilit and three angels, and also in Arabic, Syriac, and Modern Greek texts.

In Byzantine-Greek, Southern Slavic, Romanian, Coptic, Ethiopian, and Eastern Slavic Traditions Sisinnius and characters with similar names can be met quite regularly. At the same time the name of Sisinnius (Sisin or Sisoi) can be met in Mikhail-type and Sisinnius/Melitene-type only among Southern Slavs.

In general, the name of Sisinnius is typical mainly for "Sisinnius/Melitenetype." In different variants it is presented in Byzantine-Greek, Southern Slavic, Romanian, Coptic, and Ethiopian versions of this type. In Mikhail-type texts, the name Sisinnius exists among Southern Slavs, Romanians, Eastern Slavs, and Armenians. In Armenian texts Sisinnius functions relatively rarely, appearing in one line with many other characters.

Based on the data about relations between the two types of SL, we may infer that the name of St Sisinnius appeared first in the texts of "Sisinnius/Melitene-type." Most likely it happened in Byzantine-Greek tradition, which from one side influenced South Slavic and Romanian traditions, and from the other Coptic and Ethiopian traditions. In Eastern Slavic charms against tryasavitsy Sisinnius can appear under Byzantine-Greek and Southern Slavic influence. At the same time, the angel Sikhael undoubtedly appears in Russian charms from ByzantineGreek texts [I2].

Researchers have offered several hypothesizes about the historical and mythological prototypes of Sisinnius. In Byzantine-Greek, Southern Slavic, Romanian, Russian, Coptic, Ethiopian, and Armenian traditions, Sisinnius is identified as a concrete character from a church legend. For example, the Coptic church has included the plot of SL in the Story of the Holy Life of Saint Sisinnius of Nicomedia. In Egypt, no later than the fourth century A.C., there formed a local cult of Saint Sisinnius [3, p. I73]. In the Russian tradition, Sisinnius as a character for charms against fever is associated with three other Sisinniuses (Sisinnius Sevastiisky, Sisinnius from Laodicea, and Sisinnius Kizichesky). In the episode of the torment of Sisinnius, Archbishop Kizichesky is sporadically depicted on Russian icons together with images of tryasavitsy. Iconographic materials show that in 
different cultures under the name of Sisinnius, different characters were assumed. For example, on Coptic frescos and textile crafts, and Ethiopian magical prayer rolls, Sisinnius is depicted as an armed rider, but on Russian icons he is painted as an old holy man in a bishop's toggery.

In addition to illustrated manuscripts, there are visual representations of SL on the famous fresco from Egyptian Bawit, on Coptic textile crafts, in an Ethiopian easel painting, in Old Russian figurines, Russian iconography, etc. Wall posters depicting a plot about Lilit and three angels were spread in Jewish tradition. Pictures where female demons are chased out, punished, and killed undoubtedly were more expressive and accessible for comprehension than oral traditions of the same events.

Sisinnius can act alone, together with his brother or angel, or in a trio with two friends or brothers. The appearance near Sisinnius of another companion with a similar name (for example Sisinnius and Sisinodore, Sisinnius and Sinidore in Greek texts) or another character of Christian legend (for example, Archangel Michael or Raphael) lead to the formation of a specific sacred couple (see character pairs in written legends and iconography: Archangels Michael and Gabriel, Apostles Peter and Paul, healers Kosmas and Damian, holy soldiers Theodore Stratilatus and Theodore Tiron, Saints Flor and Lavr, Russian prince martyrs Boris and Gleb and others).

In the earliest versions of Sisinnius/Melitene-type (Aramaic and Jewish) the trio of sacred characters are met. In "The History of Smamit" on Aramaic magical cups, "angels” Soni, Sasoni, Sanigru, and Artiku appear. In Jewish charms, Lilit is chased by three angels Sanvi, Sansavi, and Samangeloph. In other texts of Sisinnius/Melitene-type, three or more sacred characters can appear and one of them can be named Sisinnius. For example, in Byzantine-Greek texts, Sisinnious, Siny, and Sinodore appear, in a South Slavic Glagolitic amulet there is Sisin', Sisinos', Sikinor', Sikisanor', and Těodor', in one Armenian charm there is Sisiane, Sisinnius, and Shikhas, in South Slavic tradition there is Sisin', Siniodor', Teodor', etc. These connections resemble other sacred trios: such as the three angels appearing to Abraham, the three wise men coming to bow to the newborn Christ, three adolescents in the cave of fire, etc.

In the names of angels from Aramaic and Jewish charms the combination of the consonants " $s-n$ " are met and later preserved in the name of Sisinnius and in many other names from SL. The appearance of the name "Si- 
sinnius" in the texts' structure of Sisinnius/Melitene-type and later in Mikhailtype likely were influenced to a certain degree by the effect of anagrammatic inertia, which has appeared in prototypes of SL and later was preserved in texts in many languages, taking at least Iooo and a half years. This general tendency appeared in the fact that many characters which take the place of Sisinnius or are used in addition to him very often have the same combination of consonants "s-n," "s-s-n," and sometimes the combination of "si-si," "se-se," "sin-sin," or "sen-sen." For example, in Russian charms the name of Sisinnius was replaced by others that are phonetically close, such as Sizinii, Sezentii, Silinii, Siphinnii, Sinei, Sisimi, Nasisenii, Sikhenei, Isasil, Sosentii, Isimon, etc. [16, pp. 65I-652).

Both SL types show the power of Sisinnius, his holiness, and his ability to command demons. There are several ways that Sisinnius' name and characters with phonetically close names have been made sacred:

I. Sisinnius and his companions are called saints, angels, apostles, Christ's disciples, great solders, etc.

2. Sisinnius is assumed to take actions that are typical for this or that character of religious legends (for example, he comes down from Mount Sinai as Moses or Ilya the Prophet).

3. Demons acknowledge the power of Sisinnius over them and swear to obey the religious incantations and magic spells in which this name is mentioned, making his name identical to other sacred names, but first of all to the name of Christ.

4. Sisinnius and his companions may be followed by angels, apostles, and saints. In Russian charms against fever, Sisinnius acts in the same way as archangels Sichael, Michael, and Raphael.

In SL, the topic of name as a tool of magic influence is skillfully developed. The manipulation of names is an important element of SL's plot because it gives the texts their special efficiency. Sisinnius or other male characters interrogate a female demon, forcing her to pronounce her names, and with this they receive power over her. The motif of recording the names connects a SL text with the practice of making amulets.

The names of female demons and angels included in SL play a special role in the text and may be used separately from the basic text, for example as a list. In different SL versions, the magic power can belong to the whole text or just to the 
mentioned names only (which could be the names of saints and demons). From the functional point of view, the name of a saint and the name of the female demon work as tools to command and obey.

The written forms of SL allow the perception of it not only as a magic means of influence over evil power, but as a fixed document of agreement between the sacred character and demon that is obligatory for both sides. In this case, the written text has a higher status than the oral one because it represents a hardcopy document that can be compared with other manuscripts of religious and juridical content. In general, the act of making magical manuscripts sacred was typical of not only highly educated people, but also of the half educated or even illiterate people who may have perceived a book as an attribute of religious and/or secular power. The names of Sisinnius and a female demon (included in the text of a charm) serve as their signatures which witness the authenticity of their agreement, its legitimacy, and the responsibility taken by both sides.

Table 2 - Characters in the texts of Sisinnius/Melitene-type

\begin{tabular}{|c|c|c|c|c|}
\hline № & $\begin{array}{l}\text { Ethnolinguistic } \\
\text { versions of Sisinnius/ } \\
\text { Melitene-type }\end{array}$ & $\begin{array}{l}\text { Sacred characters } \\
\text { (protectors) }\end{array}$ & Victims & Demons \\
\hline I & Aramaic & $\begin{array}{l}\text { Sini, Sasini, Snigri, } \\
\text { and Artiki }\end{array}$ & Smamit & Siderous \\
\hline 2 & Jewish & $\begin{array}{l}\text { The angels Sanvi, } \\
\text { Sansavi, and } \\
\text { Samangeloph }\end{array}$ & - & Lilit \\
\hline 3 & Coptic & $\begin{array}{l}\text { Sisinnius, } \\
\text { St Susniius }\end{array}$ & $\begin{array}{l}\text { The sister of St } \\
\text { Susniius }\end{array}$ & $\begin{array}{l}\text { Werzilya, } \\
\text { Alabastriya, the } \\
\text { sister of St Susniius }\end{array}$ \\
\hline 4 & Arabic & - & - & - \\
\hline 5 & $\begin{array}{l}\text { Ethiopian (magic } \\
\text { manuscripts) }\end{array}$ & $\begin{array}{l}\text { St Sisinnius (as a } \\
\text { rider with a spear) }\end{array}$ & $\begin{array}{l}\text { A wife of Sisinnius } \\
\text { (no name) }\end{array}$ & $\begin{array}{l}\text { Werzilya, Werzeliya, } \\
\text { Aberzeliya }\end{array}$ \\
\hline 6 & $\begin{array}{l}\text { Ethiopian } \\
\text { (hagiographic works) }\end{array}$ & $\begin{array}{l}\text { St Sisinnius (as a } \\
\text { rider with a spear) }\end{array}$ & $\begin{array}{l}\text { The sister of St } \\
\text { Sisinnius } \\
\text { (Anastasia) }\end{array}$ & $\begin{array}{l}\text { The sister of } \\
\text { St Sisinnius } \\
\text { (Anastasia) }\end{array}$ \\
\hline 7 & Classical Syriac (?) & Simon Keefa & $\begin{array}{l}\text { The Tsar's wife (no } \\
\text { name) }\end{array}$ & Demon \\
\hline 8 & Armenian & - & - & - \\
\hline
\end{tabular}




\begin{tabular}{|l|l|l|l|l|}
\hline 9 & Byzantine Greek & $\begin{array}{l}\text { St Sisinnius, Siny, } \\
\text { and Sinodore }\end{array}$ & $\begin{array}{l}\text { The sister of St } \\
\text { Sisinnius } \\
\text { (Melitene) }\end{array}$ & Gylou \\
\hline IO & Modern Greek & Five brothers & $\begin{array}{l}\text { Their sister } \\
\text { Melitene }\end{array}$ & $\begin{array}{l}\text { Evil neighbour Suda, } \\
\text { Muda }\end{array}$ \\
\hline II & South Slavic & $\begin{array}{l}\text { St Sisin, St Sison, } \\
\text { St Sisoi and others }\end{array}$ & $\begin{array}{l}\text { The sister of St Sisin } \\
\text { Melitene, Melentia }\end{array}$ & $\begin{array}{l}\text { Devil, enemy, Satan, } \\
\text { veshtitsa }\end{array}$ \\
\hline I2 & Romanian & $\begin{array}{l}\text { St Sisin, St Sisoi, } \\
\text { Isidore, and } \\
\text { Theodore }\end{array}$ & Melentiia, Meletiya & Devil \\
\hline I3 & Eastern Slavic & - & - & - \\
\hline
\end{tabular}

Table 3 - Characters in the texts of "Mikhail-type"

\begin{tabular}{|l|l|l|l|}
\hline № & $\begin{array}{l}\text { Ethnolinguistic } \\
\text { versions of } \\
\text { "Mikhail-type" }\end{array}$ & Sacred Characters (protectors) & Demons \\
\hline 1 & $\begin{array}{l}\text { "The Testament of } \\
\text { Solomon" }\end{array}$ & Solomon, the angel Rafael & Obyzouth, Abizut \\
\hline 2 & Aramaic & $\begin{array}{l}\text { The “angels" Soni, Sasoni, } \\
\text { Sanigru, and Artiku }\end{array}$ & Smamit \\
\hline 3 & Jewish & Prophet Ilijah, Angel Michael & $\begin{array}{l}\text { Lilit, the Star Margalit, } \\
\text { Ashtribo }\end{array}$ \\
\hline 4 & Coptic & - & - \\
\hline 5 & Arabic & Solomon & Karina \\
\hline 6 & Ethiopian & - & - \\
\hline 7 & Classical Syriac & The anchorite Avdisho & Teb'a \\
\hline 8 & Armenian & $\begin{array}{l}\text { St Peter, St Paul, St Sisinnii, } \\
\text { St Sianii, and others }\end{array}$ & Al, Tpcha \\
\hline 9 & Byzantine Greek & Archangel Michael & Gylou, Avizu, and others \\
\hline 10 & Modern Greek & Angel Michael, Christ & Ellu, Vaskantira \\
\hline 11 & South Slavic & Archangel Michael, St Sisin & Veshtitsa \\
\hline 12 & Romanian & $\begin{array}{l}\text { St Sisoi / Sisin, Archangel } \\
\text { Michael }\end{array}$ & Aveshtitsa / Avestitsa; Avizukha \\
\hline 13 & Eastern Slavic & $\begin{array}{l}\text { St. Sisinnii, Angel Sikhaiel, } \\
\text { Michael, Rafael, Apostles, and } \\
\text { others }\end{array}$ & Tryasavitsy \\
\hline & & & \\
\hline
\end{tabular}

Female characters play the role of demons in the majority of investigated traditions. In Jewish texts this is Lilit, in Byzantine-Greek Gylou, in Southern 
Slavic veshtitsa, in Romanian avestitsa, in Syriac Teb'a, in Ethiopian Werzelya, in Arabic Karina, in Modern Greek an evil neighbour Suda (Muda), in Russian 7 or I2 tryasavitsy. Nevertheless, in a set of traditions male demons appear; in Aramaic texts this is Siderous, in Armenian it is $\mathrm{Al}$ and Tpcha, in the Syriac "Incantation of Simon Keefa against Teb'a," it is a demon.

If a culture knows two types of SL plots, female characters may coincide and differ within them. For example, in Byzantine-Greek texts Gylou is met in both types of texts. In Southern Slavic texts there is veshtitsa in Mikhail-type and a devil (who is sometimes replaced by a veshtitsa) in the texts of Sisinnius/Melitene-type. In Romanian texts there are avestitsa and Avizukha in Mikhail-type and the devil in the texts of Sisinnius/Melitene-type.

In the SL onomasticon female names number much more than male. If male names mostly have parallels in Christian legends, then female names are often taken from folklore or are meaningless words. In general, the names of female demons are much less stable than the name of Sisinnius. As a rule, while translating the text to another language, the name of a female demon was changed to another one which was more characteristic of the receiving culture.

One of the first lists of names appears on an Aramaic magic terracotta cup inscription in which a charmer numerates the demons whom he ties with his incantation [5, pp. 34-36). But cases when a female demon pronounces her names by herself are more significant for the tradition of SL. The earliest such list exists in a Byzantine-Greek charm of Mikhail-type written on a lead tablet from the $8^{\text {th }}$ century and was discovered in Cyprus. This list includes 12 names and each of them has a concrete serial number ("the first name is this, the second name is that..." etc.) [17, pp. 27I-273). The motifs of interrogation and listing names later are met in Southern Slavic and Romanian texts of Mikhail-type and Sisinnius/ Melitene-type and also in Jewish, Syriac, and Armenian texts of Mikhail-type. In Modern Greek texts of both types and in Aramaic, Coptic, and Ethiopian texts of Sisinnius/Melitene-type these motifs are absent.

In Russian and Ukrainian charms against fever, it is not a list of names of one female demon, but different names of the 7 or 12 daughters of Herod; these names are motivated by their characteristics and describe symptoms of the disease they cause. 


\section{Reasons for the Longevity and Widespread of SL}

The longevity of SL is explained by the concrete social functions which it had and by its usage by people who learned these texts, copied, preserved, pronounced, and transferred them to others. On one hand, different versions of SL allowed for the resolution of the practical tasks of family protection and the preservation of healthy descendants; on the other hand, they had a rather entertaining character and it was interesting to read and retell them.

The historiola of SL can be simultaneously represented by:

I) A narration with a plot, which has an entertaining character and is formed for memorizing and retranslation.

2) A magic text with skillfully included sacred names and performative sayings (incantations and swears).

3) A description of a case event which leads to the victory of sacred powers over demons and guarantes the protection from them in the future.

4) A scenario of a magic act which is performed in the process of text recitation.

Handwritten manuscripts of SL versions are a peculiar material embodiment of an agreement of peace between a human being and demons. Thanks to a lucky combination of narrative and magical functions SL has been stably preserved and reproduced for centuries.

The central plot of Mikhail-type, which includes the meeting of two or more characters and their dramatic confrontation, is extremely productive for the construction of different narrative structures and their reworking and development of different meanings. In different traditions, this plot was modified in the way which was the most adequate for the needs of the society and was included in the acting of socially-meaningful functions. For example, in Jewish tradition (where beliefs about Lilith were very popular) SL became a protective charm and/or an amulet against this demoness.

The flexibility of SL played an important role too. It not only was translated into other languages, but it "grew" in new oral and literary cultures, included different characters of authentic folklore tradition, and was perceived not only as a story about the past, but as a vital and necessary tool to repel against the devilish powers attacking people from different sides.

Despite the many differences in cultures where SL is known, there are definite constants. In particular, beliefs about demonesses putting harm on women in 
labor and newborn infants are widely spread among peoples of the Balkans, Caucasus, Near East, and Northern and Eastern Africa. It was these cultures where SL texts (which could protect pregnant women and babies from powerful demonesses) stayed active during approximately one thousand and a half years. Significantly, when SL came to the Eastern Slavs (in whose traditions the function of a harmful demoness is not very representative) SL changed its functional vector and transformed into a charm against fever.

In the analyzed traditions SL was documented in written forms and because of this it could be preserved during centuries and transferred across large distances. Magical manuscripts and amulets could be ordered and were sold for money, which is why low-level clergy were interested in the existence of this tradition.

The stability of SL was supported by the fact that orthodox cultures had been relatively tolerant in the preservation of their folk beliefs and popular religious practices in contrast to Western Christian attitudes. There was a broad transitional zone between the church cult and common religious culture, where magic texts functioned parallel to oral traditions and written ones. It is also important that throughout the centuries people supported their faith in the saving power of holy warriors and the angels' hierarchy. At the same time, diseases, bad luck, and the evil eye were personified in the images as female demons.

The idea of a massive spread of texts lays in the SL structure and because of it the legends function as a "machine" generating new texts. Special verbal formulae included in the swear of demoness or incantation of sacred characters aim to motivate a person to copy, preserve, and perform the SL text. Situations with written amulet preservation and situations with the performance of oral charms were both incorporated into the tradition. In the first case it was necessary to copy and acquire an amulet with the text of a charm (possibly with illustrations), preserve this amulet at home, or carry it on the body. In the second case it was necessary to learn the text of a charm with the names of its characters and pronounce it when necessary. In some traditions of SL it includes such phrases as, "Let nothing happen to whoever has this amulet."

Mechanical copying of SL texts took place when they were multiplied by printing method. For example, Romanians and Southern Slavs included SL texts in popular editions. Wall posters with averters against Lilit were printed in Jewish tradition. 
The way of SL distribution resembles the functioning of a computer virus [25, p. 70). When first getting into the new environment SL gains the new language shell, modifies, and adapts to the cultural surroundings. Then a triggering mechanism is switched on and the updated structure begins to produce texts intensively and distributes them in the net. To make a user open a delivered letter it is necessary to address this letter to a user personally and to promise to resolve his own problems. Exactly this tempting offer is provided in SL texts.

The most massive distribution of SL texts happened on the south and north periphery of existence of this tradition - in Ethiopia and in Russia. This corresponds to the general regularity according to which not the central area, but marginal and peripheral zones better preserve archaic phenomena. The cultural situation also plays its own role. In Ethiopia and in Russia there were worked out the stable forms of popular religiosity which combined features of church and near-church cult together with "low" religious practices and believes.

Translated by Alexandra Curtis and Yelena Minyonok

\section{Список литературы}

I Агапкина T.A. Сисиниева молитва у южных славян // Сисиниева легенда в фольклорных и рукописных традициях Ближнего Востока, Балкан и Восточной Европы / отв. ред. А.Л. Топорков. М.: Индрик, 20I7. С. 373-506.

Гусарова Е.В. Легенда о святом Сисинии и Верзилье в эфиопской традиции // Сисиниева легенда в фольклорных и рукописных традициях Ближнего Востока, Балкан и Восточной Европы / отв. ред. А.Л. Топорков. М.: Индрик, 2017. C. I4I-I92.

3 Каковкин А.Я. Две ткани VIII века из Эрмитажа с изображением святого Сисиния // Византийский временник. М.: Наука, 2003. Т. 62 (87). С. I70-I75. Каспина M.M. Еврейские заговоры и амулеты от Лилит и Сисиниева легенда // Сисиниева легенда в фольклорных и рукописных традициях Ближнего Востока, Балкан и Восточной Европы / отв. ред. А.Л. Топорков. М.: Индрик, 2017. С. $87-\mathrm{I} 32$. Лявданский А.К. Арамейская версия сюжета Сисиниевой легенды // Сисиниева легенда в фольклорных и рукописных традициях Ближнего Востока, Балкан и Восточной Европы / отв. ред. А.Л. Топорков. М.: Индрик, 20I7. С. 29-62.

6 Лявданский А.К. «Завещание Соломона» и генезис Сисиниевой легенды // Сисиниева легенда в фольклорных и рукописных традициях Ближнего Востока, 
Балкан и Восточной Европы / отв. ред. А.Л. Топорков. М.: Индрик, 2017. С. $63-86$.

Лявданский А.К. Арабские версии Сисиниевой легенды // Сисиниева легенда в фольклорных и рукописных традициях Ближнего Востока, Балкан и Восточной Европы / отв. ред. А.Л. Топорков. М.: Индрик, 20I7. С. І93-202.

Лявданский А.К., Нуруллина А.С. Сирийская версия Сисиниевой легенды // Сисиниева легенда в фольклорных и рукописных традициях Ближнего Востока, Балкан и Восточной Европы / отв. ред. А.Л. Топорков. М.: Индрик, 20I7. С. 203-24I. Мазилу М., Тимотин Э. Легенда о святом Сисинии в румынской традиции // Сисиниева легенда в фольклорных и рукописных традициях Ближнего Востока, Балкан и Восточной Европы / отв. ред. А.Л. Топорков. М.: Индрик, 2017. C. 507-552. Папазян А.А. Лилит // Мифы народов мира: Энциклопедия.

М.: Изд-во «Советская энциклопедия», г982. Т. 2. С. 55 .

Пассалис X. Сохранение и трансформация Сисиниевой молитвы в новогреческих заговорах // Сисиниева легенда в фольклорных и рукописных традициях Ближнего Востока, Балкан и Восточной Европы / отв. ред. А.Л. Топорков. М.: Индрик, 20I7. С. 315-326. Рычков А.Л. Ангел, имеющий власть над лихорадкой, и Сисиниева молитва // Сисиниева легенда в фольклорных и рукописных традициях Ближнего Востока, Балкан и Восточной Европы / отв. ред. А.Л. Топорков. М.: Индрик, 2017. C. $689-750$. Рычков А.Л. Сакральный персонаж Сисиниевой легенды: о предыстории имени и образа // Сисиниева легенда в фольклорных и рукописных традициях Ближнего Востока, Балкан и Восточной Европы / отв. ред. А.Л. Топорков. М.: Индрик, 2017. C. $75 \mathrm{I}^{-} 77 \mathrm{O}$. Соколов М.И. Материалы и заметки по старинной славянской литературе. М.: Унив. тип., І888. Вып. І. 328 с.

Тадевосян Т.В., Коцинян Ш.К. Армянские амулеты и заговоры против ала и тпхи и Сисиниева легенда // Сисиниева легенда в фольклорных и рукописных традициях Ближнего Востока, Балкан и Восточной Европы / отв. ред.

А.Л. Топорков. М.: Индрик, 20I7. С. 327-372.

Топорков А.Л. Сисиниева легенда и заговоры от лихорадки у восточных славян // Сисиниева легенда в фольклорных и рукописных традициях Ближнего Востока, Балкан и Восточной Европы / отв. ред. А.Л. Топорков. М.: Индрик, 20I7. С. 553-688. фольклорных и рукописных традициях Ближнего Востока, Балкан и Восточной Европы / отв. ред. А.Л. Топорков. М.: Индрик, 20I7. С. 242-304.

Чернецов С.Б. Эфиопская картина собрания МАЭ (№ 2594-I4) и легенда о святом Сисинии и Верзилье // Из культурного наследия народов Америки и Африки. 
Л.: Наука, Ленинградское отделение, I975. С. 200-207 (Сб. Музея антропологии и этнографии. Т. 3I).

I9 Cassuto U. Un antico scongiuro ebraico contro Lilit // Estratto. Rivista degli studi orientali. Roma: Sapienza - Universita di Roma, I934. Vol. XV, fasc. II-III. P. 259-26I.

20 Fauth $W$. Der christliche Reiterfolge des Sisinnios-Typs im Kampf gegen eine vielnämige Dämonin // Vigiliae christianae. Vol. 53. Leiden; Boston; Köln: Brill Academic Publishers, I999. P. 4OI-425. Gaster M. Two Thousand Years of a Charm against the Child-Stealing Witch // Folklore. London: David Nutt, for The Folk-Lore Society, I900. T. II. P. I29-I62. Giannobile S. Un dialogo tra l'arcangelo Michele e il demone Abyzou in un'iscrizione esorcistica cipriota // Mediterraneo antico. Vol. 7. Roma: Istituti Editoriali e Poligrafici Internazionali, 2004. P. 727-750.

23 Greenfield R. Saint Sisinnios, the Archangel Michael and the Female Demon Gylou: The Typology of the Greek Literary Stories // Byzantina. I989. Vol. I5. P. 83-I4I.

24 Ohrt F. Segen // Handwörterbuch des deutschen Aberglaubens. Berlin; Leipzig: Verlag Walter de Gruyter, I935/1936. Bd 7. S. I582-1620.

25 Panchenko A. The Beast Computer in Brussels: Religion, Conspiracy Theories, and Contemporary Legends in Post-Soviet Culture // Folklore. Electronic Journal of Folklore. Tartu, 20I7. vol. 69. P. 69-90. URL: http://www.folklore.ee/folklore/vol69/ panchenko.pdf

26 Preisendanz K. Ein Wiener Papyrusfragment zum Testamentum Salomonis // Eos. Commentarii Societatis Philologiae Polonorum. Wratislavia: Polskie Towarzystwo Filologiczne, I956. Vol. 48. P. I6I-I67.

27 Worrell W.H. Abyssinian Amulets // Hastings Encyclopaedia of Religion and Ethics. Edinburg, I9IO. P. 399-400.

\section{References}

I Agapkina T.A. Sisinieva molitva u iuzhnykh slavian [The Sisinnius prayer among South Slavs]. Sisinieva legenda v fol'klornykh i rukopisnykh traditsiiakh Blizhnego Vostoka, Balkan $i$ Vostochnoi Evropy [St Sisinnius' legend in folklore and written traditions of the Near East, Balkans and Eastern Europe]. Moscow, Indrik Publ., 20I7, pp. 87-I32. (In Russ.) Gusarova E.V. Legenda o sviatom Sisinii i Verzil'e v efiopskoi traditsii [The Legend about St Sisinnius and Verzilya in the Ethiopian tradition]. Sisinieva legenda $v$ fol'klornykh i rukopisnykh traditsiiakh Blizhnego Vostoka, Balkan i Vostochnoi Evropy [St Sisinnius' legend in folklore and written traditions of the Near East, Balkans, and Eastern Europe]. Moscow, Indrik Publ., 20I7, pp. I4I-I92. (In Russ.)

Kakovkin A. Ya. Dve tkani VIII veka iz Ermitazha s izobrazheniem sviatogo Sisiniia [Two textiles of the $8^{\text {th }}$ century with the image of St Sisinnius from the State Hermitage 
Museum]. Vizantiiskii vremennik [The Byzantine Chronicle]. Moscow, Nauka Publ., 2003, vol. 62 (87), pp. I70-I75. (In Russ.)

Kaspina M.M. Evreiskie zagovory i amulety ot Lilit i Sisinieva legenda [Jewish charms and amulets against Lilit and the Sisinnius Legend]. Sisinieva legenda $v$ fol'klornykh $i$ rukopisnykh traditsiiakh Blizhnego Vostoka, Balkan i Vostochnoi Evropy [St Sisinnius' legend in folklore and written traditions of the Near East, Balkans, and Eastern Europe]. Moscow, Indrik Publ., 20I7, pp. 87-I32. (In Russ.)

Liavdanskii A.K. Arameiskaia versiia siuzheta Sisinievoi legendy [The Aramaic version of the plot of the Sisinnius Legend]. Sisinieva legenda $v$ fol'klornykh i rukopisnykh traditsiiakh Blizhnego Vostoka, Balkan i Vostochnoi Evropy [St Sisinnius' legend in folklore and written traditions of the Near East, Balkans, and Eastern Europe]. Moscow, Indrik Publ., 2017, pp. 29-62. (In Russ.)

6 Liavdanskii A.K. "Zaveshchanie Solomona" i genezis Sisinievoi legendy ["The Testament of Solomon" and the genesis of the Sisinnius Legend]. Sisinieva legenda $v$ fol'klornykh i rukopisnykh traditsiiakh Blizhnego Vostoka, Balkan i Vostochnoi Evropy [St Sisinnius' legend in folklore and written traditions of the Near East, Balkans, and Eastern Europe]. Moscow, Indrik Publ., 2017, pp. 63-86. (In Russ.) Liavdanskii A.K. Arabskie versii Sisinievoi legendy [Arabic versions of the Sisinnius Legend]. Sisinieva legenda v fol'klornykh i rukopisnykh traditsiiakh Blizhnego Vostoka, Balkan $i$ Vostochnoi Evropy [St Sisinnius' legend in folklore and written traditions of the Near East, Balkans, and Eastern Europe]. Moscow, Indrik Publ., 2017, pp. 193-202. (In Russ.) Liavdanskii A.K., Nurullina A.S. Siriiskaia versiia Sisinievoi legendy [The Syrian version of the Sisinnius legend]. Sisinieva legenda v fol'klornykh i rukopisnykh traditsiiakh Blizhnego Vostoka, Balkan i Vostochnoi Evropy [St Sisinnius' legend in folklore and written traditions of the Near East, Balkans, and Eastern Europe]. Moscow, Indrik Publ., 20I7, pp. 203-24I. (In Russ.)

9 Mazilu M., Timotin E. Legenda o sviatom Sisinii v rumynskoi traditsii [The legend of St Sisinnius in the Romanian tradition]. Sisinieva legenda v fol'klornykh i rukopisnykh traditsiiakh Blizhnego Vostoka, Balkan i Vostochnoi Evropy [St Sisinnius' legend in folklore and written traditions of the Near East, Balkans, and Eastern Europe].

Moscow, Indrik Publ., 20I7, pp. 507-552. (In Russ.) tions. Encyclopedia]. Moscow, Sovetskaia entsiklopediia Publ., I982, vol. 2, p. 55. (In Russ.)

Passalis X. Sokhranenie i transformatsiia Sisinievoi molitvy v novogrecheskikh zagovorakh [Preservation and transformation of the Sisinnius prayer in the Modern Greek charms]. Sisinieva legenda v fol'klornykh i rukopisnykh traditsiiakh Blizhnego Vostoka, Balkan i Vostochnoi Evropy [St Sisinnius' legend in folklore and written traditions of the Near East, Balkans, and Eastern Europe]. Moscow, Indrik Publ., 20I7, pp. 3I5-326. (In Russ.) 
Rychkov A.L. Angel, imeiushchii vlast' nad likhoradkoi, i Sisinieva molitva [The angel who has power over fever and the Sisinnius prayer]. Sisinieva legenda $v$ fol'klornykh $i$ rukopisnykh traditsiiakh Blizhnego Vostoka, Balkan i Vostochnoi Evropy [St Sisinnius' legend in folklore and written traditions of Near East, Balkans and Eastern Europe]. Moscow, Indrik Publ., 20I7, pp. 689-750. (In Russ.) Rychkov A.L. Sakral'nyi personazh Sisinievoi legendy: o predystorii imeni i obraza [The sacred character of the Sisinnius legend: prehistory of his name and image]. Sisinieva legenda v fol'klornykh i rukopisnykh traditsiiakh Blizhnego Vostoka, Balkan i Vostochnoi Evropy [St Sisinnius' legend in folklore and written traditions of the Near East, Balkans, and Eastern Europe]. Moscow, Indrik Publ., 20I7, pp. 75I-770. (In Russ.) Sokolov M.I. Materialy i zametki po starinnoi slavianskoi literature [Materials and notes on the old Slavic literature]. Moscow, Univ. Tip., I888, issue I, 328 p. (In Russ.) Tadevosian T.V., Kotsinian Sh.K. Armianskie amulety i zagovory protiv ala i tpkhi i Sisinieva legenda [Armenian amulets and charms against $\mathrm{Al}$ and Tpcha and the Sisinnius legend]. Sisinieva legenda v fol'klornykh i rukopisnykh traditsiiakh Blizhnego Vostoka, Balkan i Vostochnoi Evropy [St Sisinnius' legend in folklore and written traditions of the Near East, Balkans, and Eastern Europe]. Moscow, Indrik Publ., 20I7, pp. 327-372. (In Russ.)

I6 Toporkov A.L. Sisinieva legenda i zagovory ot likhoradki u vostochnykh slavian [The Sisinnius legend and charms against fever among Eastern Slavs]. Sisinieva legenda $v$ fol'klornykh i rukopisnykh traditsiiakh Blizhnego Vostoka, Balkan i Vostochnoi Evropy [St Sisinnius' legend in folklore and written traditions of the Near East, Balkans, and Eastern Europe]. Moscow, Indrik Publ., 20I7, pp. 553-688. (In Russ.) Chekha O.V. Sisinieva molitva v vizantiiskoi traditsii [The Sisinnius prayer in the Byzantine tradition]. Sisinieva legenda $v$ fol'klornykh i rukopisnykh traditsiiakh Blizhnego Vostoka, Balkan $i$ Vostochnoi Evropy [St Sisinnius' legend in folklore and written traditions of the Near East, Balkans, and Eastern Europe]. Moscow, Indrik Publ., 20I7,

pp. 242-304.

I8 Chernetsov S.B. Efiopskaia kartina sobraniia MAE (№ 2594-I4) i legenda o sviatom Sisinii i Verzil'e [Ethiopic collection in the funds of MAE (№ 2594-I4) and the legend about St. Sisinnius and Werzelya]. Iz kul'turnogo naslediia narodov Ameriki i Afriki [From the cultural heritage of the peoples of America and Africa]. Sb. Muzeya antropologii i etnografii, vol. 3I. Leningrad, Nauka, Leningradskoye otdeleniie Publ., I975, pp. 200-207. (In Russ.)

I9 Cassuto U. Un antico scongiuro ebraico contro Lilit. Estratto. Rivista degli studi orientali. Roma, Sapienza - Universita di Roma, I934. Vol. XV, fasc. II-III. P. 259-26I. (In Italian)

Fauth W. Der christliche Reiterfolge des Sisinnios-Typs im Kampf gegen eine vielnämige Dämonin. Vigiliae christianae. Leiden; Boston; Köln, Brill Academic Publishers, I999, vol. 53, pp. 4OI-425. (In German) 
2I Gaster M. Two Thousand Years of a Charm against the Child-Stealing Witch. Folklore. London, David Nutt, for The Folk-Lore Society, I900, vol. II, pp. I29-I62.

(In English)

22 Giannobile S. Un dialogo tra l'arcangelo Michele e il demone Abyzou in un'iscrizione esorcistica cipriota. Mediterraneo antico. Roma, Istituti Editoriali e Poligrafici Internazionali, 2004, vol. 7, pp. 727-750. (In Italian)

23 Greenfield R. Saint Sisinnios, the Archangel Michael and the Female Demon Gylou: The Typology of the Greek Literary Stories. Byzantina, I989, vol. I5, pp. 83-I4I. (In English)

24 Ohrt F. Segen. Handwörterbuch des deutschen Aberglaubens. Berlin; Leipzig, Verlag Walter de Gruyter, I935/I936. Bd 7. S. I582-I620. (In German)

25 Panchenko A. The Beast Computer in Brussels: Religion, Conspiracy Theories, and Contemporary Legends in Post-Soviet Culture. Folklore. Electronic Journal of Folklore. Tartu, 20I7. vol. 69. P. 69-90. Available at: http://www.folklore.ee/folklore/vol69/ panchenko.pdf (In English)

26 Preisendanz K. Ein Wiener Papyrusfragment zum Testamentum Salomonis. Eos. Commentarii Societatis Philologiae Polonorum. Wratislavia, Polskie Towarzystwo Filologiczne, I956, vol. 48, pp. I6I-I67. (In Latin)

27 Worrell W.H. Abyssinian Amulets. Hastings Encyclopaedia of Religion and Ethics. Edinburg, I9I0, pp. 399-400. (In English) 